\title{
Effect of ascorbic acid on morphology of post-thawed human adipose-derived stem cells
}

\author{
Komang Ardi Wahyuningsih ${ }^{1,2,3}$, Karina Karina ${ }^{2,3}$, Imam Rosadi ${ }^{3}$, Iis Rosliana ${ }^{3}$, Wismo Reja Subroto ${ }^{3}$ \\ ${ }^{1}$ Department of Histology, Universitas Katolik Indonesia Atma Jaya, Jakarta, Indonesia; ${ }^{2}$ Klinik Hayandra, ${ }^{3}$ Hayandra Lab, Yayasan Hayandra Peduli, \\ Jakarta, Indonesia \\ Contributions: (I) Conception and design: KA Wahyuningsih, K Karina, I Rosadi; (II) Administrative support: None; (III) Provision of study \\ material or patients: K Karina; (IV) Collection and assembly of data: I Rosadi, I Rosliana, WR Subroto; (V) Data analysis and interpretation: KA \\ Wahyuningsih, I Rosadi; (VI) Manuscript writing: All authors; (VII) Final approval of manuscript: All authors. \\ Correspondence to: Komang Ardi Wahyuningsih. Department of Histology, Universitas Katolik Indonesia Atma Jaya, Jakarta, Indonesia. \\ Email: komang.wahyuningsih@atmajaya.ac.id.
}

Background: Ascorbic acid-2-phosphate has been reported to play a role in cell division and to suppress aging of cell. However, post-thawed cell morphology on various concentration of ascorbic acid is still unclear. In this study, we aimed to observe the morphology of post-thawed adipose-derived stem cells (ADSCs) in medium containing L-ascorbic acid-2-phosphate (LAA2P) (50 and $100 \mu \mathrm{g} / \mathrm{mL})$.

Methods: The cells were isolated from adipose tissue. Isolated cells then cultured and cryopreserved in liquid nitrogen. We detected mRNA expression of type 1 collagen on day 5 . Cell seeded in T25 flask using basal medium [Dulbecco's modified Eagle's medium (DMEM) only] as a control group, DMEM with 10\% fetal bovine serum (FBS) and antibiotics as DMFA group, while DMFA with ascorbic acid (50 and $100 \mu \mathrm{g} / \mathrm{mL})$ as ascorbic acid treatment group.

Results: The results showed that the cells cultured in DMEM only attached until 96 hours of observation while serum groups with or without ascorbic acid supplementation showed the proliferation until 240 hours of observation. The highest spread size of cell was in a serum group without ascorbic acid supplementation and the highest yield of cells showed in a group with $50 \mu \mathrm{g} / \mathrm{mL}$ of ascorbic acid supplementation. Reduced mRNA expression of type 1 collagen which related to aging was showed in cells cultured without ascorbic acid supplementation.

Conclusions: These results showed that ascorbic acid increased the cell division and suppressed the aging processes indicated by normal spread cell in size compared to cell cultured in DMFA without ascorbic acid supplementation.

Keywords: Ascorbic acid; stem cells; morphology; senescence; post-thawed

Received: 10 March 2020; Accepted: 13 August 2020; Published: 02 September 2020.

doi: $10.21037 /$ sci-2020-011

View this article at: http://dx.doi.org/10.21037/sci-2020-011

\section{Introduction}

Mesenchymal stem cells (MSCs) have the ability to differentiate into several types of cells including adipocyte, chondrocyte, osteocytes and hold promise for application in regenerative medicine $(1,2)$. The source of MSCs that many studied and reported is from bone marrow which well known as bone marrow stem cells (BMSCs) and/or lipoaspirate which is known as adipose-derived stem cells (ADSCs) $(3,4)$. However, human adult BMSCs is known to be painful, invasive, and low cell number upon harvesting compared to ADSCs (5). ADSCs as a cell source support many studies to discover nature of adult stem cells including their stemness towards physical stress such as post freezethawed processes.

To use MSCs for regenerative treatment, usually the cells 
Table 1 Primer design

\begin{tabular}{llc}
\hline Gene & \multicolumn{1}{c}{ Nucleotide base } & $\begin{array}{c}\text { Base } \\
\text { number }\end{array}$ \\
\hline GAPDH & CAAGAGCACAAGAGGAAGAGAG & 22 \\
Forward & CTACATGGCAACTGTGAGGAG & 22 \\
Reverse & & \\
Type 1 collagen & AGAGTGGAGCAGTGGTACTA & 21 \\
Forward & GATACAGGTTTCGCCAGTAGAG & 22 \\
\hline
\end{tabular}

GAPDH, glyceraldehyde-3-phosphate dehydrogenase.

are cryopreserved in liquid nitrogen (6-8). However, freezethawed cells decreased their viability and physiology of cells. To maintain their potential and hold aging processes, ascorbic acid might be as an alternative solution to suppress senescence due to their ability to suppress reactive oxidative stress (9). Ascorbic acid can increase the proliferation rate of cell during in vitro culture $(10,11)$.

Human MSCs are unable to synthesize ascorbic acid which means ascorbic acid should be added in culture medium as supplementation. In order to make receipt of common culture medium, Dulbecco's modified Eagle's medium (DMEM) supplemented with 10\% fetal bovine serum (FBS) and antibiotics (DMFA). In this study, we added L-ascorbic acid-2-phosphate (LAA2P) (50 and $100 \mu \mathrm{g} / \mathrm{mL}$ ) to DMFA and analyzed the morphology of ADSCs compared to the cells cultured without ascorbic acid supplementation. This study aimed to observe spread cell size towards ascorbic acid supplementation. Thus, this study aim was to evaluate the dose of ascorbic acid towards postthawed cells on their morphologies and sizes.

\section{Methods}

The study was conducted in accordance with the Declaration of Helsinki (as revised in 2013). The liposuction protocol was approved by the Ethical committee of Dharma Nugraha Hospital (No. 001/SkeI-Kom/RSDN/I/2020) and informed consent was taken from the participant.

\section{Cell culture}

Subcutaneous adipose tissue from abdomen was obtained from one donor undergoing liposuction procedure with age of 46. Isolation of stromal vascular fraction was followed
H-Remedy protocol (12) which involved enzymatic process, and incubation at $37{ }^{\circ} \mathrm{C}, 300 \mathrm{rpm}, 1$ hour. Isolated cells then cultured to expand the cells using in house media then cryopreserved in several tubes. The cells that we used in this study were post-thawed cells. The cells were thawed and cultured in DMEM (Gibco, USA) only for control with seeding density 1,275 per $\mathrm{cm}^{2}$, DMEM with $10 \%$ FBS (Biowest, USA), and $1 \%$ antibiotic-antimycotic (ABAM) (Gibco, USA) for DMFA group, and DMFA with 50 and $100 \mu \mathrm{g} / \mathrm{mL}$ of LAA2P for ascorbic acid groups. The cells were cultured at $37{ }^{\circ} \mathrm{C}$ in $5 \% \mathrm{CO}_{2}$, and the medium was changed every 3 days.

\section{Cells spread morphology}

In this study, we compared the effect of ascorbic acid supplementation towards post-thawed cells recovery. The control was DMEM only while DMEM with $10 \%$ FBS and $1 \%$ ABAM was DMFA group, while DMFA with $50 \mu \mathrm{g} / \mathrm{mL}$ LAA2P and DMFA with $100 \mu \mathrm{g} / \mathrm{mL}$ LAA2P were ascorbic acid groups. The observation was conducted at 1, 3, 6, 24, $48,96,144,168,240 \mathrm{~h}$ using inverted microscope (OPTICA microscope) (objective 10x). The cell spread size was calculated using ImageJ program.

\section{Tryphan blue staining}

Cells were seeded and cultured in T25 flask (1,275 cells per $\mathrm{cm}^{2}$ ) up to 10 days. Cells were harvested using Tryple Select (Gibco, USA) for cells detachment then washed it. Viable cells were counted using Trypan blue staining method.

\section{$m R N A$ expression of type 1 collagen}

The cells in treatment groups were harvested on day 5 . RNA isolation, synthesis cDNA and mRNA expression analysis were performed by SV Total RNA Isolation System (Promega, USA) and GoTaq ${ }^{\circledR}$ 2-Step RT-qPCR System (Promega, USA) following manufacturer instruction. The mRNA expression was type 1 collagen and glyceraldehyde3-phosphate dehydrogenase (GAPDH) as gene reference (Table 1). The cycle conditions were an initial denaturation step of $95^{\circ} \mathrm{C}$ for $2 \mathrm{~min}$, followed by 40 cycles of denaturation at $95{ }^{\circ} \mathrm{C}$ for $15 \mathrm{~s}$, and annealing at $54.4{ }^{\circ} \mathrm{C}$ for $1 \mathrm{~min}$, and a final extension at $60-95^{\circ} \mathrm{C}$ for $5 \mathrm{~s}$. The result of qPCR was analysed following the $2^{-\Delta \Delta C T}$ method described by Livak and Schmittgen. 

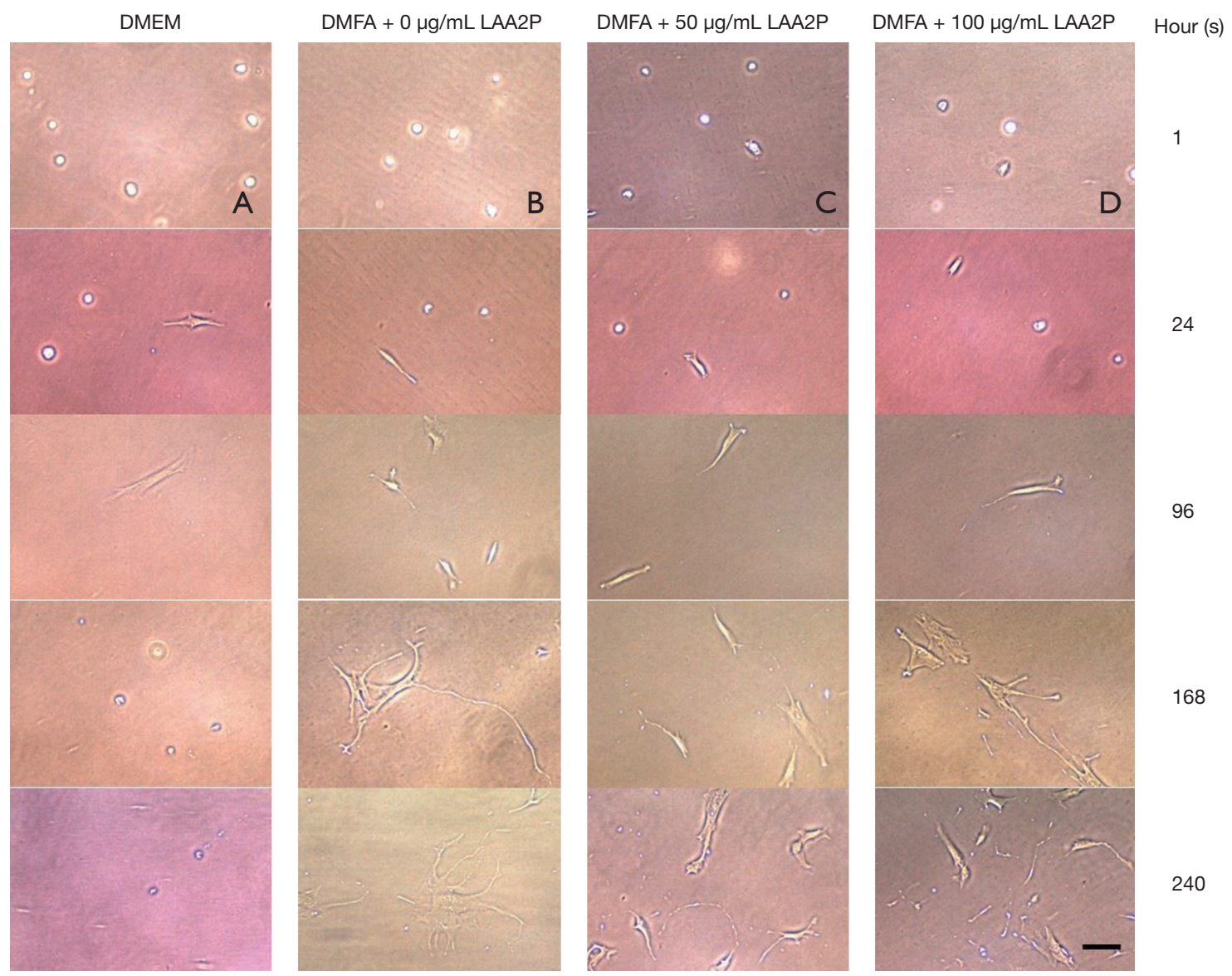

Figure 1 Post-thawed cell on morphology cultured in basal media (DMEM) (A), DMFA + $0 \mu \mathrm{g} / \mathrm{mL} \mathrm{LAA} 2 \mathrm{P}(\mathrm{B}), \mathrm{DMFA}+50 \mu \mathrm{g} / \mathrm{mL}$ LAA2P (C), and DMFA + $100 \mu \mathrm{g} / \mathrm{mL}$ LAA2P (D), objective 10×, black bar =100 $\mu \mathrm{m}$. DMEM, Dulbecco's modified Eagle's medium; LAA2P, L-ascorbic acid-2-phosphate.

\section{Statistical analysis}

Significance tests were done using individual $t$-test for normally distributed data and Mann-Whitney $U$ for nonnormally distributed data, with $\mathrm{P}$ value less than 0.05 considered as statistically significant.

\section{Results}

After 1-hour incubation at $37^{\circ} \mathrm{C}$, the cells did not show spreading sign while after 24 hours of incubation, all of the group including control which cultured in basal medium (DMEM only) was spread (Figure 1). The maximum spreading of control group was shown after 96 hours of incubation then cells were detached. In contrast, medium supplemented by serum with or without ascorbic acid showed the cells proliferated. The cells cultured in basal medium (DMEM) showed spread curve of cells with the highest peak shown after 96 hours of observation then continued to sharply decreased indicated the cells died (Figure 2).

The spread size of cell without ascorbic acid supplementation showed had the largest spreading cell in average at 240 hours of observation (Figure 3). However, ascorbic acid maintains the proper size of the cells. Interestingly, the proper concentration of ascorbic acid also has a role in yield outcome (Figure 4).

The highest yield of cells reported when cells cultured with serum containing $50 \mu \mathrm{g} / \mathrm{mL}$ of ascorbic acid compared to other groups (Figure 4). It was related to the small size of cells which supplemented by $50 \mu \mathrm{g} / \mathrm{mL}$ of ascorbic acid. Supplementation of 50 and $100 \mu \mathrm{g} / \mathrm{mL}$ of ascorbic acid 


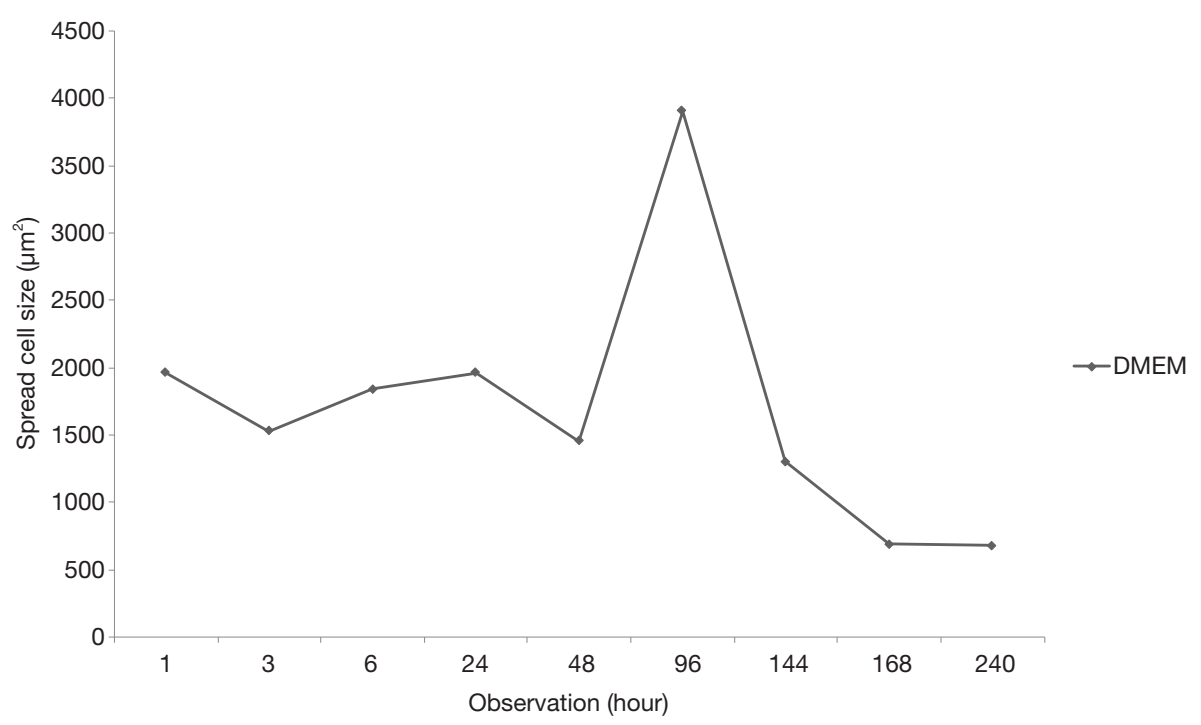

Figure 2 Cell spread size cultured in basal media (DMEM) showed the highest size was confirmed on hour 96 which be used as standard. DMEM, Dulbecco's modified Eagle's medium.

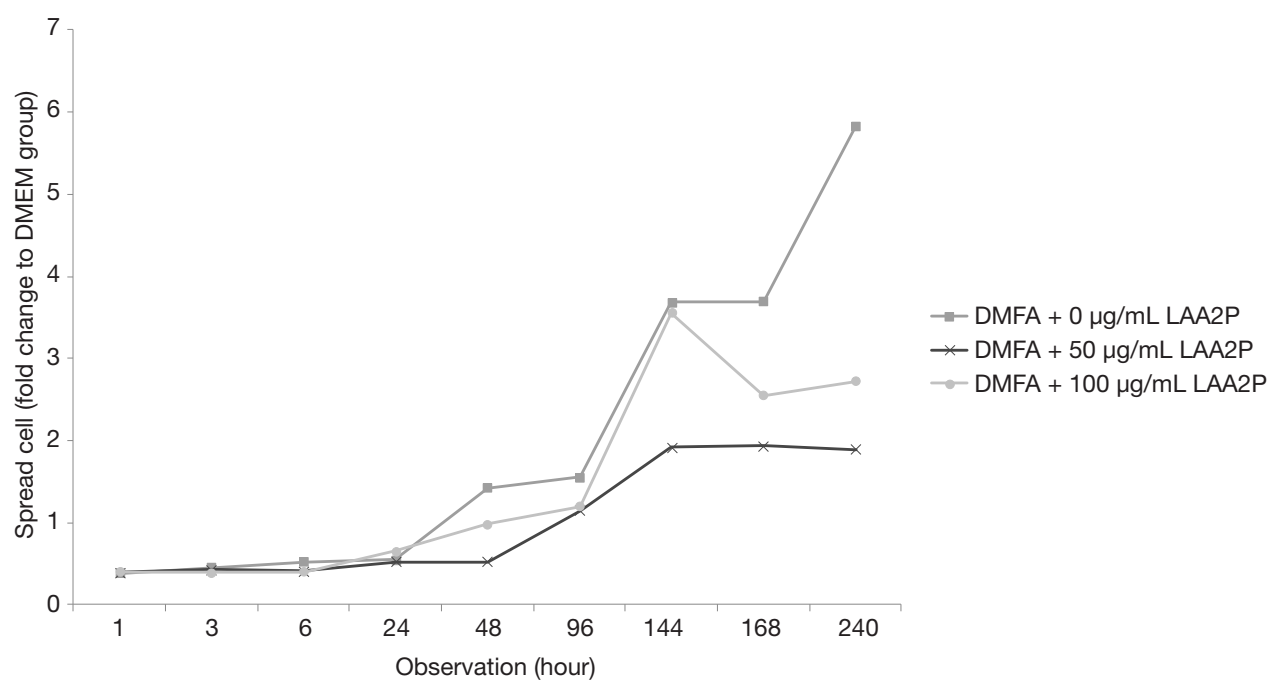

Figure 3 Cell size in various medium DMFA with or without LAA2P towards the highest cell size in basal media. LAA2P, L-ascorbic acid2-phosphate; DMEM, Dulbecco's modified Eagle's medium.

also enhanced type 1 collagen (Figure 5). However, no significant difference in the collagen expression was seen for the different ascorbic acid concentrations. The illustration of cell attachment and spreading in this study showed in Figure 6. At first, cells attach to the substrate then spread together with cell division processes. However, the size of cell was getting bigger when cells were not supplemented with ascorbic acid.

\section{Discussion}

In this study, post-thawed cells exhibited fibroblast-like shape and adhered to the plastic culture flask. It was characterized by cell morphology with filopodia on the surface that depended on the cell adhesion mechanism (13). Cryopreservation does not affect MSCs morphology, surface marker expression, differentiation or proliferation potential (14). However, additional various concentrations of ascorbic 


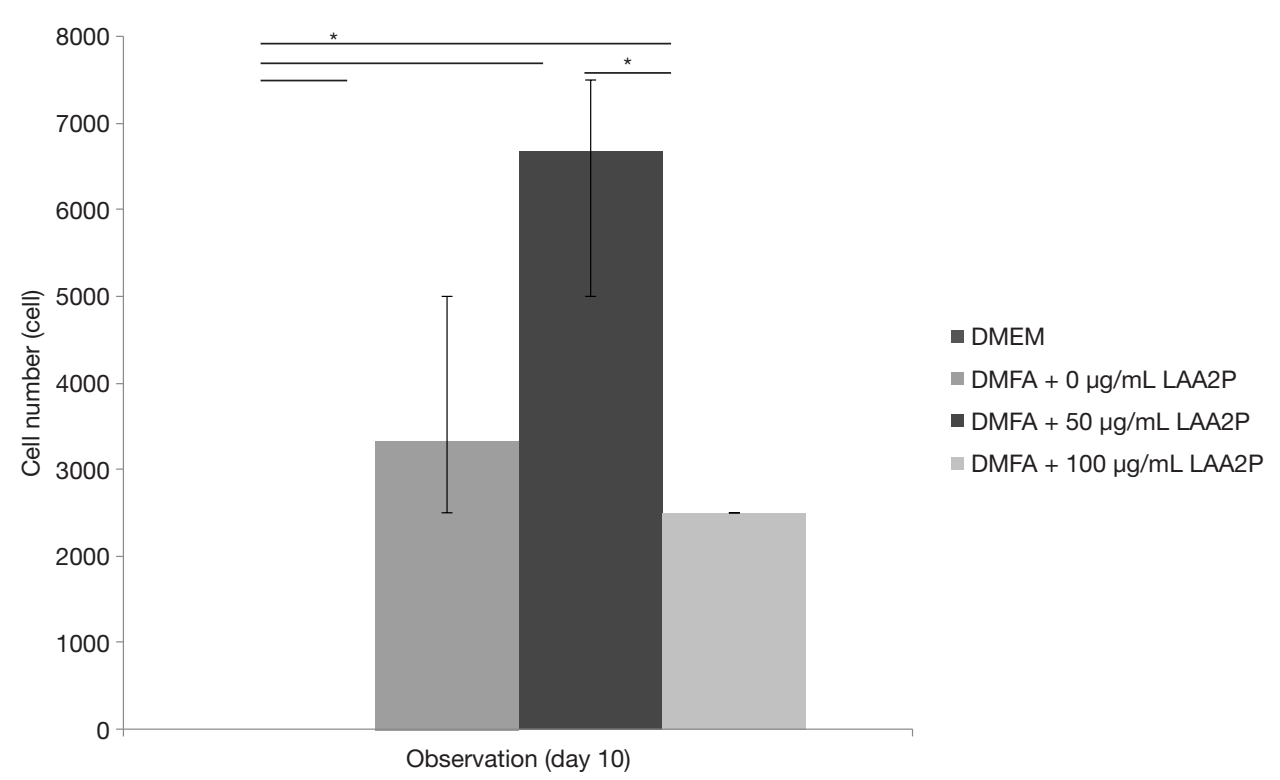

Figure 4 Cell number after 240 hours of observation, concentration of ascorbic acid has a role in proliferation of cells. *, $\mathrm{P}<0.05$. DMEM, Dulbecco's modified Eagle's medium; LAA2P, L-ascorbic acid-2-phosphate.

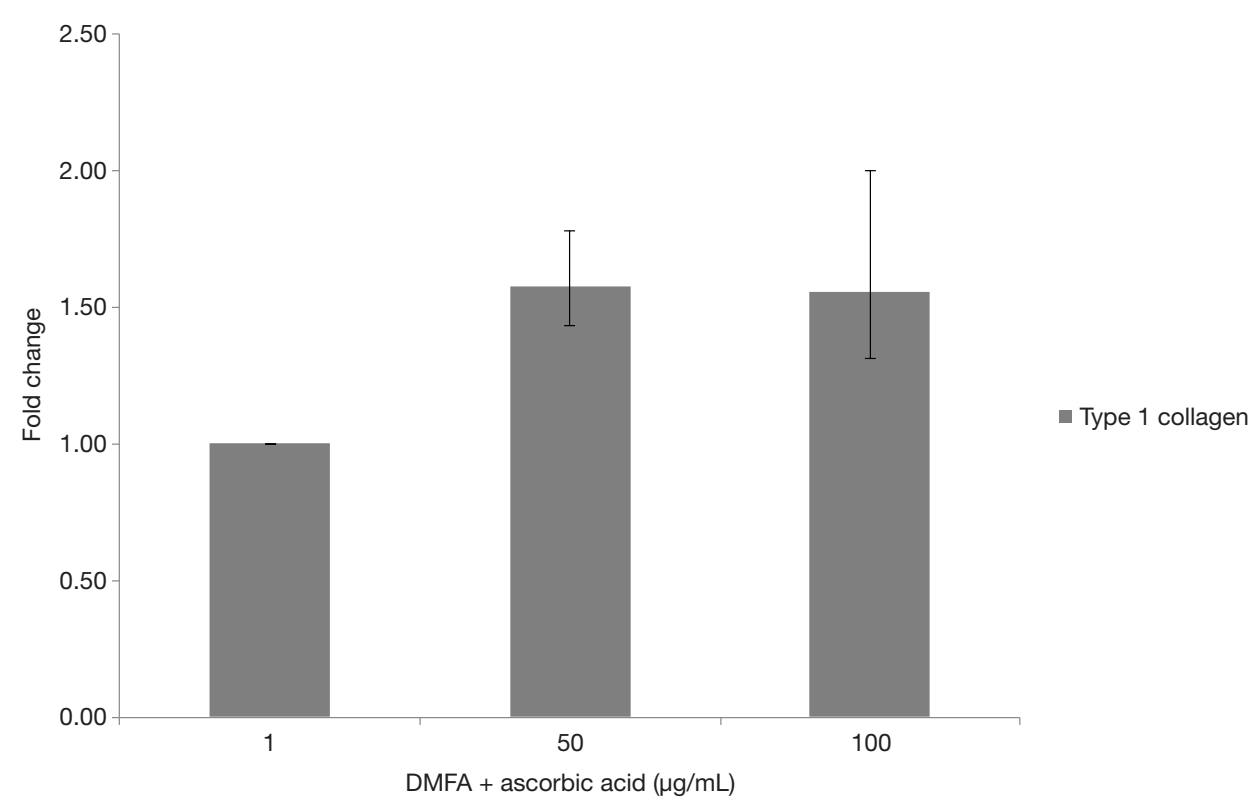

Figure 5 Type 1 collagen expression of cells cultured in various concentration of ascorbic acid after 120 hours of incubation.

acid in medium might show different results. Ascorbic acid could be used as an alternative cardiomyogenic inducing factor for human amniotic fluid MSCs (15). Ascorbic acid also supports BMSCs proliferation and promotes HIF $1 \alpha$ breakdown as well as activates mitochondria, affecting cell proliferation and metabolism. A deficit of ascorbic acid in the culture medium decreases the activity of ascorbic aciddependent enzymes (9).

The spreading size of cell in DMEM medium continuously increased during 1 hour of observation. After that, the highest spreading cell in size had been observed after 96 hours of incubation. This highest peak of spreading 
A

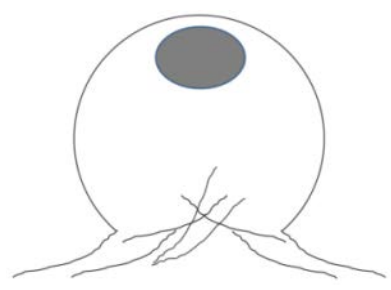

B

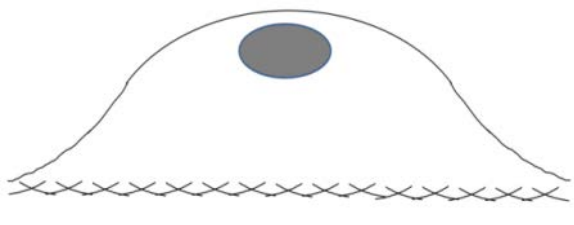

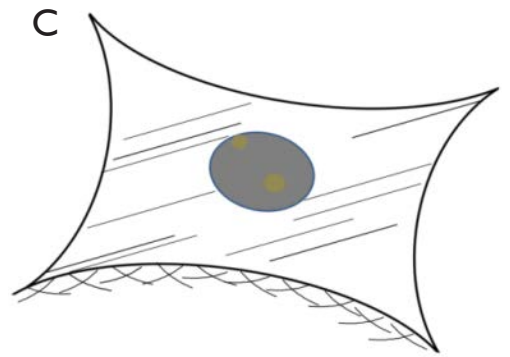

Figure 6 Illustration of cell attachment, less than 24 hours some cells were in a half spread (A); continues with spreading in average size compared to control (B), over spreading of cell was observed in group of DMFA without ascorbic acid supplementation (C).

cell was used as a standard to other groups which contained serum and ascorbic as well. Comparable effect of FBS only versus their combination with ascorbic acid was reported by Rosadi et al. (16) showed that in $1 \%$ ascorbic acid, the spread size of cells was smaller than control. The highest spread size of the cells and repeated cell division known as Hayflick phenomenon is a sign of senescence (17). Ascorbic acid has a role of multiple physiological functions involved in cell division and suppresses aging (18).

Medium supplementation with ascorbic acid increased proliferation rate and markedly increased number of cell doublings before reaching senescence, with a greater than 1,000 -fold increase in total cell numbers compared with control cultures (19). In this study, there was increased yield in the cell with $50 \mu \mathrm{g} / \mathrm{mL}$ of ascorbic acid compared to other groups. In contrast, higher concentration of ascorbic acid $(100 \mu \mathrm{g} / \mathrm{mL})$ showed decreased in yield. It is suggested that ascorbic acid has negative feedback towards its concentration. Wu et al. (20) reported that the dose-dependent effect of ascorbic acid-induced oxidative cytotoxicity and its negative correlation with higher seeding density and smaller intercellular distance. In addition to the enhanced recruitment of anti-oxidative capabilities with more cells in high-density culture conditions, higher seeding density also exerted a defensive effect against the ascorbic acid-induced oxidative stress by enhancing the expression of anti-oxidative enzymes. Other studies reported that supplementing ascorbic acid in high concentration increased intracellular reactive oxygen species levels via the production of hydrogen peroxide $\left(\mathrm{H}_{2} \mathrm{O}_{2}\right)(21,22)$. Thus, ascorbic acid can inhibit GAPDH and induce apoptosis $(23,24)$. In addition, reduction of type 1 collagen expression increased ageing damages on human dermal fibroblast (25). In this study showed that ascorbic acid increased type 1 collagen on human ADSCs and suppressed ageing processes.

We demonstrated that adding ascorbic acid in proper concentration as supplementation might help cell to suppress their senescence processes and increase proliferation rate. Furthermore, the result of cell harvested demonstrated that ascorbic acid also increased the cell proliferation rate proved by highest yield counted. However, at present, the sample size and molecular side study is limited to be conducted. Therefore, further studies are required to increase sample sizes and conduct the molecular study to improve the results.

\section{Conclusions}

In conclusion, serum with ascorbic acid $(50 \mu \mathrm{g} / \mathrm{mL})$ could be considered as an effective dose to suppress aging on postthawed cell morphology represented by the smaller spread cell size compared to control.

\section{Acknowledgments}

Funding: None.

\section{Footnote}

Conflicts of Interest: All authors have completed the ICMJE uniform disclosure form (available at http://dx.doi. org/10.21037/sci-2020-011). The authors have no conflicts of interest to declare.

Ethical Statement: The authors are accountable for all aspects of the work in ensuring that questions related to the accuracy or integrity of any part of the work are appropriately investigated and resolved. The study was conducted in accordance with the Declaration of Helsinki (as 
revised in 2013). The liposuction protocol was approved by the Ethical committee of Dharma Nugraha Hospital (No. 001/SkeI-Kom/RSDN/I/2020) and informed consent was taken from the participant.

Open Access Statement: This is an Open Access article distributed in accordance with the Creative Commons Attribution-NonCommercial-NoDerivs 4.0 International License (CC BY-NC-ND 4.0), which permits the noncommercial replication and distribution of the article with the strict proviso that no changes or edits are made and the original work is properly cited (including links to both the formal publication through the relevant DOI and the license). See: https://creativecommons.org/licenses/by-nc-nd/4.0/.

\section{References}

1. Saulite L, Jekabsons K, Klavins M, et al. Effects of malvidin, cyanidin and delphinidin on human adipose mesenchymal stem cell differentiation into adipocytes, chondrocytes and osteocytes. Phytomedicine 2019;53:86-95.

2. Vaz C, Tee BTB, Yong D, et al. Mesenchymal stromal cells derived from human embryonic stem cells, fetal limb and bone marrow share a common phenotype but are transcriptionally and biologically different. Stem Cell Discovery 2017;7:1-26.

3. Lin H, Sohn J, Shen H, et al. Bone marrow mesenchymal stem cells: Aging and tissue engineering applications to enhance bone healing. Biomaterials 2019;203:96-110.

4. Rosadi I, Karina K, Rosliana I, et al. In vitro study of cartilage tissue engineering using human adipose-derived stem cells induced by platelet-rich plasma and cultured on silk fibroin scaffold. Stem Cell Res Ther 2019;10:369.

5. Macias MI, Grande J, Moreno A, et al. Isolation and characterization of true mesenchymal stem cells derived from human term decidua capable of multilineage differentiation into all 3 embryonic layers. Am J Obstet Gynecol 2010;203:495.e9-23.

6. Moll G, Geißler S, Catar R, et al. Cryopreserved or fresh mesenchymal stromal cells: only a matter of taste or key to unleash the full clinical potential of MSC therapy? Adv Exp Med Biol 2016;951:77-98.

7. Baust JM, Corwin WL, VanBuskirk R, et al. Biobanking: the future of cell preservation strategies. Adv Exp Med Biol 2015;864:37-53.

8. Yong KW, Choi JR, Wan Safwani WK. Biobanking of human mesenchymal stem cells: future strategy to facilitate clinical applications. Adv Exp Med Biol 2016;951:99-110.
9. Fujisawa K, Hara K, Takami T, et al. Evaluation of the effects of ascorbic acid on metabolism of human mesenchymal stem cells. Stem Cell Res Ther 2018;9:93.

10. Lin HY, Lai RH, Lin ST, et al. Suppressor of cytokine signaling 6 (SOCS6) promotes mitochondrial fission via regulating DRP1 translocation. Cell Death Differ 2013;20:139-53.

11. Sato H, Takahashi M, Ise H, et al. Collagen synthesis is required for ascorbic acid-enhanced differentiation of mouse embryonic stem cells into cardiomyocytes. Biochem Biophys Res Commun 2006;342:107-12.

12. Moegni KF, Rosliana I, Remelia M, et al. Stromal vascular fraction (SVF) therapy for treatment of various diseases: delivering safety of the first patented svf technique in indonesia. Cytotherapy 2019;21:S86.

13. Kang JM, Rajangam T, Rhie JW, et al. Characterization of cell signaling, morphology, and differentiation potential of human mesenchymal stem cells based on cell adhesion mechanism. J Cell Physiol 2020;235:6915-28.

14. Bahsoun S, Coopman K, Akam EC. The impact of cryopreservation on bone marrow-derived mesenchymal stem cells: a systematic review. J Transl Med 2019;17:397.

15. Markmee R, Aungsuchawan S, Pothacharoen P, et al. Effect of ascorbic acid on differentiation of human amniotic fluid mesenchymal stem cells into cardiomyocytelike cells. Heliyon 2019;5:e02018.

16. Rosadi I, Karina K, Rosliana I, et al. The effect of human platelet-rich plasma and L-ascorbic acid on morphology, proliferation, and chondrogenesis ability towards human adipose-derived stem cells. Molecular and Cellular Biomedical Sciences 2019;3:26-33.

17. Wagner W, Horn P, Castoldi M, et al. Replicative senescence of mesenchymal stem cells: a continuous and organized process. PLoS One 2008;3:e2213.

18. Fujisawa K, Terai S, Hirose $Y$, et al. Senescence marker protein 30 (SMP30)/regucalcin (RGN) expression decreases with aging, acute liver injuries and tumors in zebrafish. Biochem Biophys Res Commun 2011;414:331-6.

19. Gharibi B, Hughes FJ. Effects of medium supplements on proliferation, differentiation potential, and in vitro expansion of mesenchymal stem cells. Stem Cells Transl Med 2012;1:771-82.

20. Wu YK, Tu YK, Yu J, et al. The influence of cell culture density on the cytotoxicity of adipose-derived stem cells induced by L-ascorbic acid-2-phosphate. Sci Rep 2020;10:104.

21. Uetaki M, Tabata S, Nakasuka F, et al. Metabolomic alterations in human cancer cells by vitamin $\mathrm{C}$-induced 
oxidative stress. Sci Rep 2015;5:13896.

22. Clément MV, Ramalingam J, Long LH, et al. The in vitro cytotoxicity of ascorbate depends on the culture medium used to perform the assay and involves hydrogen peroxide. Antioxid Redox Signal 2001;3:157-63.

23. Yun J, Mullarky E, Lu C, et al. Vitamin C selectively kills KRAS and BRAF mutant colorectal cancer cells by targeting GAPDH. Science 2015;350:1391-6.

doi: $10.21037 /$ sci-2020-011

Cite this article as: Wahyuningsih KA, Karina K, Rosadi I, Rosliana I, Subroto WR. Effect of ascorbic acid on morphology of post-thawed human adipose-derived stem cells. Stem Cell Investig 2020;7:16.
24. Li CJ, Sun LY, Pang CY. Synergistic protection of $\mathrm{N}$-acetylcysteine and ascorbic acid 2-phosphate on human mesenchymal stem cells against mitoptosis, necroptosis and apoptosis. Sci Rep 2015;5:9819.

25. Wang T, Guo S, Liu X, et al. Protective effects of adipose-derived stem cells secretome on human dermal fibroblasts from ageing damages. Int J Clin Exp Pathol 2015;8:15739-48. 